Research article

Open Access

\title{
Breast cancer susceptibility loci and mammographic density
}

\author{
Rulla M Tamimi ${ }^{1}, 2$, David Cox ${ }^{1,2}$, Peter Kraft ${ }^{2}$, Graham A Colditz ${ }^{3}$, Susan E Hankinson ${ }^{1,2}$ and \\ David J Hunter ${ }^{1,2}$
}

\author{
${ }^{1}$ Channing Laboratory, Department of Medicine, Brigham and Women's Hospital and Harvard Medical School, 181 Longwood Avenue, Boston, MA, \\ 02115, USA \\ 2Department of Epidemiology, Harvard School of Public Health, 677 Huntington Avenue, Boston, MA, 02115, USA \\ ${ }^{3}$ Department of Surgery, Washington University School of Medicine, 660 S. Euclid Avenue, St. Louis, MO 63110, USA
}

Corresponding author: Rulla M Tamimi, rulla.tamimi@channing.harvard.edu

Received: 6 Mar 2008 Revisions requested: 10 Apr 2008 Revisions received: 15 Jul 2008 Accepted: 5 Aug 2008 Published: 5 Aug 2008

Breast Cancer Research 2008, 10:R66 (doi:10.1186/bcr2127)

This article is online at: http://breast-cancer-research.com/content/10/4/R66

(c) 2008 Tamimi et al.; licensee BioMed Central Ltd.

This is an open access article distributed under the terms of the Creative Commons Attribution License (http://creativecommons.org/licenses/by/2.0), which permits unrestricted use, distribution, and reproduction in any medium, provided the original work is properly cited.

\begin{abstract}
Introduction Recently, the Breast Cancer Association Consortium (BCAC) conducted a multi-stage genome-wide association study and identified 11 single nucleotide polymorphisms (SNPs) associated with breast cancer risk. Given the high degree of heritability of mammographic density and its strong association with breast cancer, it was hypothesised that breast cancer susceptibility loci may also be associated with breast density and provide insight into the biology of breast density and how it influences breast cancer risk.

Methods We conducted an analysis in the Nurses' Health Study $(n=1121)$ to assess the relation between 11 breast cancer susceptibility loci and mammographic density. At the time of their mammogram, 217 women were premenopausal and 904 women were postmenopausal. We used generalised linear models adjusted for covariates to determine the mean percentage of breast density according to genotype.
\end{abstract}

Results Overall, no association between the 11 breast cancer susceptibility loci and mammographic density was seen. Among the premenopausal women, three SNPs (rs12443621 [TNRc9/ LOC643714], rs3817198 [lymphocyte-specific protein-1] and rs4666451) were marginally associated with mammographic density $(p<0.10)$. All three of these SNPs showed an association that was consistent with the direction in which these alleles influence breast cancer risk. The difference in mean percentage mammographic density comparing homozygous wildtypes to homozygous variants ranged from 6.3 to $8.0 \%$. None of the 11 breast cancer loci were associated with postmenopausal breast density.

Conclusion Overall, breast cancer susceptibility loci identified through a genome-wide association study do not appear to be associated with breast cancer risk.

\section{Introduction}

Mammographic density is one of the strongest risk factors for breast cancer. Women with $75 \%$ or more breast density are at a four- to six-fold greater risk of breast cancer than women with no density $[1,2]$. The mechanism by which mammographic density increases breast cancer risk is unclear.

Results from twin studies have estimated that inherited genetic influences account for 60 to $67 \%$ of the variation in mammographic density [3]. Given its high degree of heritability $[3,4]$, a number of studies have examined genetic variation and mammographic density utilising a candidate gene approach focusing primarily on polymorphisms in oestrogen synthesis and metabolising genes with inconclusive results [5-10]. In addition, polymorphisms in growth factor genes - such as insulin-like growth factor (IGF)-1 [11], IGF binding protein 3 [12] and pituitary growth hormone [13] - have been reported to be associated with mammographic density, although these findings have not yet been examined or replicated in independent studies.

Recently, the Breast Cancer Association Consortium (BCAC) conducted a multi-stage genome-wide association study of breast cancer cases and controls and identified 11 single nucleotide polymorphisms (SNPs) associated with risk [14]. 
The Nurses' Health Study breast cancer nested case-control study contributed to the third stage of this genome-wide association study. Given the strong association between mammographic density and breast cancer, breast cancer susceptibility loci may also be associated with breast density and provide insight into the biology of breast density and how it influences breast cancer risk. We conducted a cross-sectional study in the Nurses' Health Study $(n=1121)$ to assess the relation between breast cancer susceptibility loci identified from a multi-stage genome-wide association study and mammographic density.

\section{Materials and methods}

The Nurses' Health Study was initiated in 1976, with 121,700 US-registered nurses age 30 to 55 years returning an initial questionnaire [15]. Information on body mass index (BMI), reproductive history, age at menopause and postmenopausal hormone use, as well as diagnosis of cancer and other diseases are updated every two years through questionnaires. During 1989 and 1990, blood samples were collected from 32,826 women [16]. In general, blood samples were returned within 26 hours of being drawn and were immediately centrifuged, aliquoted into plasma, red blood cells and buffy coat fractions, and stored in liquid nitrogen freezers. The follow-up rate among women who provided blood samples was $99 \%$ through 1998.

We conducted a cross-sectional analysis among controls from a breast cancer case-control study nested within the Nurses' Health Study cohort. This nested case-control study included breast cancer cases diagnosed after blood collection but before 1 June 1998 and matched controls [17]. The collection of film mammograms was targeted to breast cancer cases and matched controls through the 1998 follow-up cycle. We collected mammograms taken as close as possible to the date of blood collection (1989 to 1990). This collection has been described in detail in a previous publication [11].

This study was approved by the Committee on the Use of Human Subjects in Research at Brigham and Women's Hospital.

To assess mammographic density, the craniocaudal views of both breasts were digitised at 261 microns/pixel with a Lumysis 85 laser film scanner, which covers a range of 0 to 4.0 optical density. The software for computer-assisted thresholding was developed at the University of Toronto [18] and this measure of mammographic breast density was highly reproducible within this study [19]. We used the average percentage density of both breasts for this analysis. We also evaluated the association of these SNPs with the absolute area of mammographic density, but because results were similar and percentage breast density has been a stronger predictor of breast cancer risk than area of dense tissue in many [1,20-23] but not all [24] studies, we present the results for percentage mam- mographic density as our primary analyses and include the association with dense and non-dense area in supplementary tables.

As part of the third stage of the BCAC multi-stage genomewide association study, 30 SNPs were genotyped in the Nurses' Health Study breast cancer nested case-control samples. Although genotype data are available for all 30 SNPs, we present results for the 11 SNPs reported to be associated with breast cancer after all three stages as our primary results. Analyses examining the association between the other 19 SNPs and breast density were considered secondary (see supplementary table 1 in additional data file 1).

Genotyping was conducted using a fluorescent 5' endonuclease assay and the ABI-PRISM 7900 (Taqman) for sequence detection. For quality control, about $10 \%$ of samples were

Table 1

Descriptive characteristics of study population $(n=1121)$ at the time of mammography, Nurses' Health Study (1989-1998)

\begin{tabular}{|c|c|c|}
\hline \multicolumn{3}{|l|}{ Characteristic } \\
\hline Mean values & Mean & SD \\
\hline Age, y & 58.4 & 7.3 \\
\hline Body mass index, $\mathrm{kg} / \mathrm{m}^{2}$ & 25.6 & 4.6 \\
\hline Percentage mammographic density, \% & 27.1 & 20.6 \\
\hline Frequencies ${ }^{a}$ & $\mathrm{~N}$ & $\%$ \\
\hline \multicolumn{3}{|l|}{ Menopausal/hormone status } \\
\hline Premenopausal & 217 & 19.4 \\
\hline Postmenopausal/never user & 371 & 33.1 \\
\hline Postmenopausal/past user & 317 & 28.3 \\
\hline Postmenopausal/current user & 216 & 19.3 \\
\hline \multicolumn{3}{|l|}{ Alcohol consumption } \\
\hline None & 327 & 31.8 \\
\hline$<5$ g/day & 346 & 33.6 \\
\hline 5 to $14.9 \mathrm{~g} /$ day & 221 & 21.5 \\
\hline $15+g /$ day & 135 & 13.1 \\
\hline \multicolumn{3}{|l|}{ Parity/age at first birth } \\
\hline Nulliparous & 83 & 7.5 \\
\hline Parous $/<25$ years & 549 & 49.6 \\
\hline Parous $/ 25$ to 29 years & 382 & 34.5 \\
\hline Parous $/>30$ & 93 & 8.4 \\
\hline Prior benign breast disease & 465 & 41.5 \\
\hline Family history of breast cancer & 135 & 12.0 \\
\hline
\end{tabular}

a Numbers may not be added to total due to missing data. 
included as blinded duplicates in the genotyping runs. The concordance for replicate samples was more than $99 \%$.

We used generalised linear models adjusted for covariates to determine the mean percentage breast density according to genotype. To determine if there was a linear trend with increasing variant alleles, we calculated $p$ values from Wald statistics including an ordinal variable for genotype regressed on square root transformed percentage mammographic density. Covariate information at the time of the mammogram was assessed using data from biennial questionnaires completed before the date of the mammogram. Although it is unlikely that these factors are confounders of the genotype and mammographic density relationship, these variables do explain the substantial variation in the outcome. In addition, genetic variants may be associated with mammographic density through its association with other covariates, such as BMI. Because our goal was to determine if breast cancer susceptibility loci are associated with mammographic density independent of factors know to influence breast density, we included known predictors of mammographic density in multivariate models.

Percentage mammographic density is considerably lower in postmenopausal women than in premenopausal women. It has been suggested that premenopausal breast density may be more highly heritable than postmenopausal density [25], and that different genes may be associated with premenopausal density rather than with postmenopausal density [26]. We therefore a priori considered that genes may differentially be associated with premenopausal and postmenopausal mammographic density. Because there was evidence that the association between some of the breast cancer susceptibility loci and breast density varied according to menopausal status at mammogram we included results stratified by menopausal status. Data analysis was conducted using SAS statistical software version 9.1. All $p$ values presented are two-sided tests of statistical significance.

\section{Results}

This study examined the association between 11 breast cancer susceptibility loci and mammographic density in 1121 women in the Nurses' Health Study. The mean age of participants at the time of mammography was 58.4 years (Table 1 ). At the time of their mammogram, 217 women were premenopausal, with a mean (SD) age at mammography of 49.1 (3.3) years. Among premenopausal women, the mean percentage mammographic density was $39.7(22.2) \%$ (range 0.6 to $90.3 \%)$. At the time of their mammogram, 904 women were postmenopausal with a mean age at mammography of 60.6 (6.2) years. Among postmenopausal women, the mean percentage mammographic density was 24.1 (19.0)\% (range 0.0 to $86.5 \%$ ). Of the postmenopausal women, $41 \%$ had never used postmenopausal hormones, $24 \%$ were currently using postmenopausal hormones and 35\% were former users at the time of their mammograms. European ancestry was selfreported by $98.8 \%$ of the women in the study.

Overall, there was no significant association between the 11 breast cancer susceptibility loci and mammographic density (Table 2). Of the 11 breast cancer susceptibility loci, three were associated with premenopausal mammographic density at $p<0.10$ (Table 3). The variant allele of rs12443621 (TNRc9/LOC643714) was positively associated with mammographic density; the mean percentage mammographic density among homozygous variants $(42.5 \%)$ was $6.3 \%$ percentage points greater than those homozygous for the wildtype allele (36.2\%). This association was primarily due to the association with dense area $(p=0.04$; see supplementary Table 2 in additional file 2), rather than non-dense area ( $p=$ 0.30; see supplementary Table 3 in additional file 3 ). The variant allele of rs3817198 (lymphocyte-specific protein-1 [LSP1]) was positively associated with mammographic density; the mean percentage mammographic density among homozygous variants $(41.0 \%)$ was $7.5 \%$ percentage points greater than those homozygous for the wildtype allele (33.5\%). This association also appears to be due to the association with dense area $(p=0.04$; see supplementary Table 2 in additional file 2), rather than with non-dense area $(p=0.15$; see supplementary Table 3 in additional file 3 ). The variant allele of rs4666451 was inversely associated with mammographic density; the mean percentage mammographic density among homozygous variants $(33.6 \%)$ was $8.0 \%$ percentage points lower than those homozygous for the wildtype allele (41.6\%). In contrast, this association was primarily due to the association with non-dense area $(p$-trend $=0.02$; see supplementary Table 3 in additional file 3 ), rather than with dense area ( $p$-trend $=0.22$; see supplementary Table 2 in additional file 2). None of the 11 breast cancer loci were associated with postmenopausal breast density (Table 3 ). We also conducted secondary analyses among postmenopausal women restricted to women who were not taking postmenopausal hormones at the time of mammography $(n=688)$. In general, these results were consistent with results among all postmenopausal women (data not shown).

In a secondary analysis, we examined the 19 additional SNPs that were genotyped in this study population as part of stage 3 of the genome-wide association study (see supplementary Table 1 in additional file 1) but were reported to not be significantly associated with breast cancer after the final stage. Two of these SNPs (rs6843340 and rs2298075) were associated with mammographic density in the population overall. rs6843340 was associated with both premenopausal and postmenopausal density, while rs2298075 was associated with only postmenopausal density (see supplementary Table 4 in additional file 4). In addition, rs10508468 was associated with premenopausal breast density and rs6469633 was associated with postmenopausal breast density only (see supplementary Table 4 in additional file 4). 
Breast Cancer Research Vol 10 No 4 Tamimi et al.

Table 2

Mean percentage of mammographic density (MD) according to breast cancer susceptibility loci, Nurses' Health Study controls (1989 to 1998)

\begin{tabular}{|c|c|c|c|c|}
\hline & & $\mathrm{N}$ & Mean \%MDa & Mean \%MDb \\
\hline \multirow[t]{3}{*}{ rs2981582 } & $\mathrm{G} / \mathrm{G}$ & 421 & 26.9 & 26.7 \\
\hline & $\mathrm{G} / \mathrm{A}$ & 539 & 26.9 & 26.6 \\
\hline & $\mathrm{A} / \mathrm{A}$ & 160 & 26.8 & 28.0 \\
\hline$p$ value ${ }^{d}$ & & & 0.56 & 0.98 \\
\hline \multirow[t]{3}{*}{ rs12443621 } & $\mathrm{A} / \mathrm{A}$ & 298 & 25.0 & 25.7 \\
\hline & $A / G$ & 561 & 27.3 & 26.9 \\
\hline & $\mathrm{G} / \mathrm{G}$ & 267 & 27.4 & 27.1 \\
\hline$p$ value ${ }^{d}$ & & & 0.12 & 0.25 \\
\hline \multirow[t]{3}{*}{ rs13281615 } & $\mathrm{A} / \mathrm{A}$ & 377 & 27.6 & 27.2 \\
\hline & $A / G$ & 553 & 25.9 & 26.3 \\
\hline & $\mathrm{G} / \mathrm{G}$ & 198 & 28.1 & 27.5 \\
\hline$p$ value ${ }^{d}$ & & & 0.90 & 0.91 \\
\hline \multirow[t]{3}{*}{ rs3817198 } & $\mathrm{A} / \mathrm{A}$ & 489 & 26.0 & 25.9 \\
\hline & $A / G$ & 491 & 27.8 & 27.8 \\
\hline & $\mathrm{G} / \mathrm{G}$ & 119 & 25.9 & 26.1 \\
\hline$p$ value ${ }^{d}$ & & & 0.95 & 0.79 \\
\hline \multirow[t]{3}{*}{ rs889312 } & $\mathrm{T} / \mathrm{T}$ & 622 & 28.3 & 28.2 \\
\hline & $\mathrm{T} / \mathrm{G}$ & 428 & 24.7 & 25.1 \\
\hline & $\mathrm{G} / \mathrm{G}$ & 76 & 28.6 & 27.3 \\
\hline$p$ value ${ }^{d}$ & & & 0.12 & 0.06 \\
\hline \multirow[t]{3}{*}{ rs4666451 } & $\mathrm{G} / \mathrm{G}$ & 405 & 26.9 & 27.4 \\
\hline & $A / G$ & 531 & 27.2 & 26.7 \\
\hline & $\mathrm{A} / \mathrm{A}$ & 184 & 25.7 & 25.8 \\
\hline$p$ value ${ }^{d}$ & & & 0.43 & 0.13 \\
\hline \multirow[t]{3}{*}{ rs2107425 } & $\mathrm{G} / \mathrm{G}$ & 572 & 27.5 & 27.5 \\
\hline & $\mathrm{G} / \mathrm{A}$ & 440 & 25.8 & 25.8 \\
\hline & $\mathrm{A} / \mathrm{A}$ & 108 & 26.7 & 26.3 \\
\hline$p$ value ${ }^{d}$ & & & 0.39 & 0.24 \\
\hline \multirow[t]{3}{*}{ rs981782 } & $\mathrm{A} / \mathrm{A}$ & 336 & 27.9 & 27.0 \\
\hline & $\mathrm{A} / \mathrm{C}$ & 544 & 26.5 & 26.9 \\
\hline & $\mathrm{C} / \mathrm{C}$ & 231 & 26.7 & 26.8 \\
\hline$p$ value ${ }^{d}$ & & & 0.15 & 0.40 \\
\hline \multirow[t]{3}{*}{ rs 8051542} & $\mathrm{G} / \mathrm{G}$ & 307 & 26.8 & 26.8 \\
\hline & $\mathrm{G} / \mathrm{A}$ & 383 & 25.7 & 25.6 \\
\hline & $\mathrm{A} / \mathrm{A}$ & 173 & 29.3 & 29.2 \\
\hline$p$ value $d$ & & & 0.67 & 0.64 \\
\hline \multirow[t]{2}{*}{ rs30099 } & $\mathrm{C} / \mathrm{C}$ & 929 & 26.9 & 27.0 \\
\hline & $\mathrm{C} / \mathrm{T}$ & 193 & 26.0 & 25.5 \\
\hline
\end{tabular}




\begin{tabular}{|c|c|c|c|c|}
\hline & $\mathrm{T} / \mathrm{T}$ & 8 & 28.0 & 24.0 \\
\hline$p$ value $d$ & & & 0.81 & 0.28 \\
\hline \multirow[t]{3}{*}{ rs3803662 } & $\mathrm{G} / \mathrm{G}$ & 590 & 26.2 & 26.4 \\
\hline & $\mathrm{G} / \mathrm{A}$ & 434 & 27.5 & 26.9 \\
\hline & $\mathrm{A} / \mathrm{A}$ & 90 & 27.1 & 28.6 \\
\hline$p$ value ${ }^{d}$ & & & 0.53 & 0.37 \\
\hline
\end{tabular}

afge adjusted.

bMultivariate adjusted for the following: age (continuous), body mass index (BMI) (continuous), alcohol consumption (none, <5 g/day, 5 to $14.9 \mathrm{~g} /$ day, $15+\mathrm{g} /$ day), age at first birth/parity (nulliparous, age at first birth $<25$, age at first birth 25 to 29 , age at first birth $>30$ ), history of benign breast disease (yes/no), family history of breast cancer (yes/no).

cMultivariate adjusted for the following: age, BMI, alcohol consumption, age at first birth/parity, history of benign breast disease, family history of breast cancer, postmenopausal status/hormone use (premenopausal, never user, current user, past user).

$\mathrm{d} p$ value based on genotype coded as ordinal variable regressed on square root transformed MD.

\section{Discussion}

In this study, we found that overall none of the breast cancer susceptibility loci were associated with mammographic density. However, some breast cancer susceptibility loci were associated with premenopausal breast density. We did not observe an association between any of these loci and postmenopausal breast density. These loci were originally identified from a three-stage genome-wide association study. The first stage of the genome-wide association study was among 390 breast cancer patients selected with a strong family history of breast cancer of at least two affected first-degree family relatives and 364 controls [14]. Women with a family history are more likely to develop breast cancer at an early age. It is known that some breast cancer risk factors are differentially associated with premenopausal and postmenopausal breast cancer [27], hence it may be the case that the specific gene contribution to density may also vary by menopausal status. However, multiple lines of evidence suggest that the determinants of breast density may differ at different ages [26,28,29]. Thus, it is possible that different sets of genetic variants may be highly associated with premenopausal and postmenopausal breast density. If this is the case it may explain why these SNPs were associated with premenopausal breast density only and not postmenopausal breast density.

A limitation of the current study is the relatively small number of premenopausal women with density measurements ( $\mathrm{n}=$ 217). Given the number of tests conducted, it is possible that these findings are the result of chance. However, the direction and strength of the association observed between the three polymorphisms and premenopausal mammographic density suggest that these genes may play an important role in determining premenopausal breast density. All three associated SNPs are consistent with the direction in which these alleles influence breast cancer risk [14]. The variant alleles of both rs12443621 and rs3817198 were associated with increasing breast density in this study and with increasing breast cancer risk in the BCAC (Odds ratio [OR] for rs12443621 homozygous variant vs homozygous wildtype $=1.23,95 \%$ confidence interval [Cl] 1.17 to 1.30 [14]; OR for rs3817198 homozygous variant vs homozygous wildtype $=1.17,95 \% \mathrm{Cl}$ 1.08 to 1.25 [14]). The variant allele of rs4666451 was inversely associated with breast density and with a reduced risk of breast cancer in the genome-wide association study (OR homozygous variant vs homozygous wildtype $=0.93$, $95 \% \mathrm{Cl} 0.87$ to 0.99 ) [14]. In addition, the difference in mean percentage mammographic density comparing homozygous wildtypes to homozygous variants ranged from 6.3 to 8.0 percentage points. These differences in mammographic density are in the same range that has been associated previously with changes in mammographic density observed with exposure to postmenopausal hormones[30,31] and tamoxifen [32]. It is estimated that a $5 \%$ higher mammographic density is associated with a $7 \%$ increase in breast cancer risk [1]; thus, the estimated risk of breast cancer associated with these three SNPs, and attributable to their influence on mammographic density, would therefore range from 1.09 to 1.12 .

Two of the three SNPs associated with premenopausal breast density are in known genes: TNRc9/LOC643714 (rs12443621) and LSP1. It is unclear what the function of the TNRc9 (also known as TOX3) gene is; however, it contains a putative high mobility group box motif which suggests that it may act as a transcription factor and this gene has been implicated in breast cancer metastasis to the bone [33]. Another variant in the TNRc9 gene (rs3803662) also emerged from an independent genome-wide association study of oestrogenreceptor positive breast cancer in an Icelandic population [34]. rs3817198 in the LSP1 gene (also known as WP43) is a cytoskeletal protein expressed in haematopoietic and endothelial cells. rs4666451 is located on $2 p$ with no known gene function, although the region did appear in genome-wide linkage analyses of familial breast cancer [35]. It remains to be seen whether these SNPs exhibit their influence on breast 
Table 3

Mean percentage mammographic density (MD) according to breast cancer susceptibility loci, Nurses' Health Study controls (1989-1998)

\begin{tabular}{|c|c|c|c|c|c|c|c|}
\hline & & \multicolumn{3}{|c|}{ Premenopausal $(n=217)$} & \multicolumn{3}{|c|}{ Postmenopausal $(n=904)$} \\
\hline & & $\mathrm{N}$ & Mean \%MDa & Mean \%MD & $\mathrm{N}$ & Mean \%MDa & Mean \%MDc \\
\hline \multirow[t]{3}{*}{ rs2981582 } & $\mathrm{G} / \mathrm{G}$ & 73 & 37.4 & 37.9 & 332 & 24.4 & 24.2 \\
\hline & $\mathrm{G} / \mathrm{A}$ & 112 & 40.5 & 40.7 & 407 & 23.9 & 23.6 \\
\hline & $\mathrm{A} / \mathrm{A}$ & 28 & 41.7 & 38.4 & 131 & 23.7 & 25.3 \\
\hline$p$ value $d$ & & & 0.27 & 0.62 & & 0.34 & 0.82 \\
\hline \multirow[t]{3}{*}{ rs12443621 } & $\mathrm{A} / \mathrm{A}$ & 51 & 36.0 & 36.2 & 236 & 22.9 & 23.4 \\
\hline & $\mathrm{A} / \mathrm{G}$ & 104 & 38.9 & 39.1 & 442 & 24.5 & 24.2 \\
\hline & $\mathrm{G} / \mathrm{G}$ & 54 & 43.7 & 42.5 & 202 & 23.5 & 23.8 \\
\hline$p$ value d & & & 0.05 & 0.06 & & 0.70 & 0.72 \\
\hline \multirow[t]{3}{*}{ rs13281615 } & $\mathrm{A} / \mathrm{A}$ & 70 & 39.7 & 38.2 & 290 & 25.2 & 25.0 \\
\hline & $\mathrm{A} / \mathrm{G}$ & 94 & 36.0 & 38.2 & 445 & 23.7 & 23.9 \\
\hline & $\mathrm{G} / \mathrm{G}$ & 47 & 45.8 & 43.1 & 144 & 22.9 & 22.8 \\
\hline$p$ value $d$ & & & 0.45 & 0.52 & & 0.36 & 0.32 \\
\hline \multirow[t]{3}{*}{ rs3817198 } & $\mathrm{A} / \mathrm{A}$ & 80 & 33.9 & 33.5 & 396 & 24.2 & 24.0 \\
\hline & $\mathrm{A} / \mathrm{G}$ & 106 & 42.6 & 42.3 & 368 & 24.4 & 24.6 \\
\hline & $\mathrm{G} / \mathrm{G}$ & 20 & 39.5 & 41.0 & 93 & 22.7 & 22.8 \\
\hline$p$ value $d$ & & & 0.04 & 0.01 & & 0.39 & 0.56 \\
\hline \multirow[t]{3}{*}{ rs889312 } & $T / T$ & 107 & 41.1 & 41.3 & 499 & 25.6 & 25.4 \\
\hline & $\mathrm{T} / \mathrm{G}$ & 89 & 38.5 & 38.2 & 321 & 21.5 & 22.1 \\
\hline & $\mathrm{G} / \mathrm{G}$ & 14 & 38.8 & 37.2 & 58 & 26.8 & 25.3 \\
\hline$p$ value $d$ & & & 0.40 & 0.21 & & 0.17 & 0.14 \\
\hline \multirow[t]{3}{*}{ rs4666451 } & $\mathrm{G} / \mathrm{G}$ & 74 & 40.7 & 41.6 & 314 & 24.0 & 24.5 \\
\hline & $\mathrm{A} / \mathrm{G}$ & 96 & 40.6 & 39.5 & 418 & 24.2 & 23.8 \\
\hline & $\mathrm{A} / \mathrm{A}$ & 36 & 33.0 & 33.6 & 144 & 24.3 & 24.3 \\
\hline$p$ value d & & & 0.13 & 0.06 & & 0.90 & 0.40 \\
\hline \multirow[t]{3}{*}{ rs2107425 } & $\mathrm{G} / \mathrm{G}$ & 105 & 41.7 & 40.7 & 449 & 24.3 & 24.6 \\
\hline & $\mathrm{G} / \mathrm{A}$ & 87 & 36.8 & 37.2 & 337 & 23.4 & 23.3 \\
\hline & $\mathrm{A} / \mathrm{A}$ & 18 & 37.5 & 39.6 & 85 & 24.6 & 23.6 \\
\hline$p$ value $d$ & & & 0.11 & 0.29 & & 0.79 & 0.37 \\
\hline \multirow[t]{3}{*}{ rs981782 } & $\mathrm{A} / \mathrm{A}$ & 64 & 37.7 & 37.5 & 258 & 25.5 & 24.6 \\
\hline & $\mathrm{A} / \mathrm{C}$ & 100 & 39.4 & 39.2 & 429 & 23.7 & 24.1 \\
\hline & $\mathrm{C} / \mathrm{C}$ & 47 & 42.3 & 42.5 & 175 & 23.2 & 23.4 \\
\hline$p$ value d & & & 0.39 & 0.27 & & 0.08 & 0.22 \\
\hline \multirow[t]{3}{*}{ rs8051542 } & $\mathrm{G} / \mathrm{G}$ & 63 & 41.0 & 40.5 & 234 & 23.2 & 23.4 \\
\hline & $\mathrm{G} / \mathrm{A}$ & 73 & 40.0 & 40.1 & 296 & 22.3 & 22.3 \\
\hline & $\mathrm{A} / \mathrm{A}$ & 32 & 37.9 & 37.8 & 137 & 27.6 & 27.3 \\
\hline$p$ value $d$ & & & 0.58 & 0.65 & & 0.36 & 0.43 \\
\hline rs30099 & $\mathrm{C} / \mathrm{C}$ & 175 & 38.8 & 38.8 & 723 & 24.4 & 24.5 \\
\hline
\end{tabular}


Mean percentage mammographic density (MD) according to breast cancer susceptibility loci, Nurses' Health Study controls (1989-1998)

\begin{tabular}{|c|c|c|c|c|c|c|c|}
\hline & $\mathrm{C} / \mathrm{T}$ & 34 & 40.5 & 39.9 & 151 & 22.6 & 22.4 \\
\hline & $\mathrm{T} / \mathrm{T}$ & 0 & & & 8 & 26.0 & 21.8 \\
\hline$p$ value ${ }^{d}$ & & & 0.45 & 0.51 & & 0.49 & 0.16 \\
\hline \multirow[t]{3}{*}{ rs3803662 } & $\mathrm{G} / \mathrm{G}$ & 107 & 37.0 & 36.9 & 458 & 23.9 & 24.1 \\
\hline & $\mathrm{G} / \mathrm{A}$ & 77 & 43.9 & 42.7 & 344 & 24.0 & 23.4 \\
\hline & $\mathrm{A} / \mathrm{A}$ & 20 & 32.7 & 36.1 & 69 & 26.5 & 28.0 \\
\hline$p$ value ${ }^{d}$ & & & 0.55 & 0.34 & & 0.64 & 0.50 \\
\hline
\end{tabular}

afge adjusted.

bMultivariate adjusted for the following: age (continuous), body mass index (BMI) (continuous), alcohol consumption (none, <5 g/day, 5 to $14.9 \mathrm{~g} /$ day, $15+\mathrm{g} /$ day), age at first birth/parity (nulliparous, age at first birth $<25$, age at first birth 25 to 29 , age at first birth $>30$ ), history of benign breast disease (yes/no), family history of breast cancer (yes/no).

cMultivariate adjusted for the following: age, BMI, alcohol consumption, age at first birth/parity, history of benign breast disease, family history of breast cancer, postmenopausal hormone use (never user, current user, past user).

$\mathrm{d} p$ value based on genotype coded as ordinal variable regressed on square root transformed MD.

cancer risk through mammographic density. Because these SNPs are associated with modest associations in breast cancer risk, larger studies with premenopausal density measurements on breast cancer cases and controls will be necessary to address this question.

SNPs in intron 2 of fibroblast growth factor receptor 2 (FGFR2) have emerged as top hits from multiple genome-wide association studies of breast cancer [14,36]. We did not detect an association between an FGFR2 (rs2981582) SNP and breast density in the current study. Homozygous variants of rs2981582 or other SNPs in high linkage disequilibrium are estimated to confer about a $60 \%$ increase in breast cancer risk relative to homozygous wildtypes [14,36]. Assuming the association between FGFR2 variants and breast cancer is mediated through breast density, one would expect to see a $33 \%$ difference in mammographic density comparing homozygous variants with homozygous wildtypes. The current study consisted of sufficiently high numbers of both premenopausal and postmenopausal women to detect such a difference. The lack of association of the SNP in FGFR2 and other breast cancer loci with breast density in this study suggests that some genes influence breast cancer risk independent of breast density.

Our primary analyses focused on the 11 SNPs identified after a multi-stage genome-wide association study with $p \leq 0.001$ in the combined analysis. We also examined 20 additional SNPs that were either no longer significant at this cutoff or not consistent with the direction originally observed. There is suggestive evidence that three of these SNPs (rs2298075, rs684340 and rs6469633) are associated with breast density in a direction consistent with the observed association with breast cancer risk. The $p$ value in the combined BCAC study for these three SNPs ranged from 0.002 to 0.13 . Thus although they were not considered significantly associated with breast cancer at the defined cutoff, their borderline significance with breast cancer risk and consistent association with breast density warrant further investigation of these SNPs in relation to breast density and breast cancer risk.

To our knowledge, this is the first study to examine the association between these replicated breast cancer susceptibility loci and mammographic density in a cancer-free population. Lee and colleagues [37] genotyped six breast cancer susceptibility loci identified from genome-wide association studies among 516 young ( $<50$ years of age) breast cancer patients. Five of these six SNPs were included in the present study. Overall, they observed no association between the SNPs and mammographic density. However, among women with oestrogen-receptor positive breast cancer rs3817198 was associated with mammographic density $(p=0.02)$. The direction of the association observed was consistent with our findings among premenopausal women.

The majority of the current study population was postmenopausal at the time of mammography and we were limited by the number of premenopausal women with breast density measurements. Given that the first stage of the genome-wide association study was among women with a strong family history, these SNPs may be more likely to be associated with premenopausal density. It remains to be seen whether other breast cancer susceptibility loci from other study designs are associated with postmenopausal breast density.

\section{Conclusion}

Overall, breast cancer susceptibility loci identified through a genome-wide association study do not appear to be associated with breast cancer risk.

\section{Competing interests}

The authors declare that they have no competing interests. 


\section{Authors' contributions}

RMT was responsible for data analyses, manuscript preparation and editing. RMT, PK, GAC and DJH made substantial contributions to the study design and to the interpretation of data. DC and SEH contributed to interpretation of data and manuscript editing. All authors read and approved the final manuscript.

\section{Additional files}

The following Additional files are available online:

\section{Additional file 1}

A Word document containing a table that lists the mean percentage of mammographic density according to second-stage single nucleotide polymorphisms (SNPs) that were not validated in stage 3 Breast Cancer Association Consortium SNPs among controls only, Nurses' Health Study controls (1989 to 1998).

See http://www.biomedcentral.com/content/ supplementary/bcr2127-S1.doc

\section{Additional file 2}

A Word document containing a table that lists the mean absolute $\left(\mathrm{cm}^{2}\right)$ dense area according to breast cancer susceptibility loci, Nurses' Health Study controls (1989 to 1998$)$.

See http://www.biomedcentral.com/content/

supplementary/bcr2127-S2.doc

\section{Additional file 3}

A Word document containing a table that lists the mean absolute $\left(\mathrm{cm}^{2}\right)$ non-dense area according to breast cancer susceptibility loci, Nurses' Health Study controls (1989 to 1998).

See http://www.biomedcentral.com/content/

supplementary/bcr2127-S3.doc

\section{Additional file 4}

A Word document containing a table that lists the mean percentage mammographic density according to second-stage SNPs that were not validated in stage 3 BCAC SNPs among controls.

See http://www.biomedcentral.com/content/ supplementary/bcr2127-S4.doc

\section{Acknowledgements}

We are grateful to the participants of the Nurses' Health Study for their outstanding dedication and commitment to the study. This work was supported by Public Health Service Grants CA087969, CA75016 and SPORE in Breast Cancer CA089393 from the National Cancer Institute, National Institutes of Health, Department of Health and Human Services. Dr Graham Colditz is supported in part by an American Cancer Society Cissy Hornung Clinical Research Professorship. The study sponsors had no role in the design of the study; the collection, analysis and interpretation of the data; the writing of the manuscript; or the decision to submit the manuscript for publication.

\section{References}

1. Byrne C, Schairer C, Wolfe J, Parekh N, Salane M, Brinton LA Hoover R, Haile R: Mammographic features and breast cancer risk: effects with time, age, and menopause status. J Nat/ Cancer Inst 1995, 87:1622-1629.

2. Boyd NF, Byng JW, Jong RA, Fishell EK, Little LE, Miller AB, Lockwood GA, Tritchler DL, Yaffe MJ: Quantitative classification of mammographic densities and breast cancer risk: results from the Canadian National Breast Screening Study. J Nat/ Cancer Inst 1995, 87:670-675.

3. Boyd NF, Dite GS, Stone J, Gunasekara A, English DR, McCredie MR, Giles GG, Tritchler D, Chiarelli A, Yaffe MJ, Hopper JL9: Heritability of mammographic density, a risk factor for breast cancer. N Engl J Med 2002, 347:886-894.

4. Pankow JS, Vachon CM, Kuni CC, King RA, Arnett DK, Grabrick DM, Rich SS, Anderson VE, Sellers TA: Genetic analysis of mammographic breast density in adult women: evidence of a gene effect. J Natl Cancer Inst 1997, 89:549-556.

5. Haiman CA, Hankinson SE, De Vivo I, Guillemette C, Ishibe N, Hunter DJ, Byrne C: Polymorphisms in steroid hormone pathway genes and mammographic density. Breast Cancer Res Treat 2003, 77:27-36.

6. Haiman CA, Bernstein L, Berg D, Ingles SA, Salane M, Ursin G: Genetic determinants of mammographic density. Breast Cancer Res 2002, 4:R5.

7. Maskarinec G, Lurie G, Williams AE, Le Marchand L: An investigation of mammographic density and gene variants in healthy women. Int J Cancer 2004, 112:683-688.

8. Takata Y, Maskarinec G, Le Marchand L: Breast density and polymorphisms in genes coding for CYP1A2 and COMT: the Multiethnic Cohort. BMC Cancer 2007, 7:30.

9. Warren R, Skinner J, Sala E, Denton E, Dowsett M, Folkerd E, Healey CS, Dunning A, Doody D, Ponder B, Luben RN, Day NE, Easton $D$ : Associations among mammographic density, circulating sex hormones, and polymorphisms in sex hormone metabolism genes in postmenopausal women. Cancer Epidemiol Biomarkers Prev 2006, 15:1502-1508.

10. Lord SJ, Mack WJ, Berg D Van Den, Pike MC, Ingles SA, Haiman CA, Wang W, Parisky YR, Hodis HN, Ursin G: Polymorphisms in genes involved in estrogen and progesterone metabolism and mammographic density changes in women randomized to postmenopausal hormone therapy: results from a pilot study. Breast Cancer Res 2005, 7:R336-344.

11. Tamimi RM, Cox DG, Kraft P, Pollak MN, Haiman CA, Cheng I, Freedman ML, Hankinson SE, Hunter DJ, Colditz GA: Common genetic variation in IGF1, IGFBP-1, and IGFBP-3 in relation to mammographic density: a cross-sectional study. Breast Cancer Res 2007, 9:R18.

12. Lai JH, Vesprini D, Zhang W, Yaffe MJ, Pollak M, Narod SA: A polymorphic locus in the promoter region of the IGFBP3 gene is related to mammographic breast density. Cancer Epidemiol Biomarkers Prev 2004, 13:573-582.

13. Mulhall C, Hegele RA, Cao H, Tritchler D, Yaffe M, Boyd NF: Pituitary growth hormone and growth hormone-releasing hormone receptor genes and associations with mammographic measures and serum growth hormone. Cancer Epidemiol Biomarkers Prev 2005, 14(11 Pt 1):2648-2654.

14. Easton DF, Pooley KA, Dunning AM, Pharoah PD, Thompson D, Ballinger DG, Struewing JP, Morrison J, Field H, Luben R, Wareham N, Ahmed S, Healey CS, Bowman R, SEARCH collaborators, Meyer KB, Haiman CA, Kolonel LK, Henderson BE, Le Marchand L, Brennan P, Sangrajrang S, Gaborieau V, Odefrey F, Shen CY, Wu PE, Wang HC, Eccles D, Evans DG, Peto J, et al:: Genomewide association study identifies novel breast cancer susceptibility loci. Nature 2007, 447:1087-1093.

15. Colditz GA, Hankinson SE: The Nurses' Health Study: lifestyle and health among women. Nat Rev Cancer 2005, 5:388-396.

16. Hankinson SE, Willett WC, Manson JE, Colditz GA, Hunter DJ, Spiegelman D, Barbieri RL, Speizer FE: Plasma sex steroid hormone levels and risk of breast cancer in postmenopausal women. J Natl Cancer Inst 1998, 90:1292-1299. 
17. Missmer SA, Eliassen AH, Barbieri RL, Hankinson SE: Endogenous estrogen, androgen, and progesterone concentrations and breast cancer risk among postmenopausal women. J Natl Cancer Inst 2004, 96:1856-1865.

18. Byng JW, Boyd NF, Little L, Lockwood G, Fishell E, Jong RA, Yaffe MJ: Symmetry of projection in the quantitative analysis of mammographic images. Eur J Cancer Prev 1996, 5:319-327.

19. Byrne C: Mammographic density and breast cancer risk: the evolution of assessment techniques and implications for understanding breast cancer. Semin Breast Dis 1999, 2:301-314.

20. Vachon CM, Brandt KR, Ghosh K, Scott CG, Maloney SD, Carston MJ, Pankratz VS, Sellers TA: Mammographic breast density as a general marker of breast cancer risk. Cancer Epidemiol Biomarkers Prev 2007, 16:43-49.

21. Ursin G, Ma H, Wu AH, Bernstein L, Salane M, Parisky YR, Astrahan M, Siozon CC, Pike MC: Mammographic density and breast cancer in three ethnic groups. Cancer Epidemiol Biomarkers Prev 2003, 12:332-338.

22. Maskarinec G, Pagano I, Lurie G, Wilkens LR, Kolonel LN: Mammographic density and breast cancer risk: the multiethnic cohort study. Am J Epidemiol 2005, 162:743-752.

23. Torres-Mejia G, De Stavola B, Allen DS, Perez-Gavilan JJ, Ferreira JM, Fentiman IS, Dos Santos Silva I: Mammographic features and subsequent risk of breast cancer: a comparison of qualitative and quantitative evaluations in the Guernsey prospective studies. Cancer Epidemiol Biomarkers Prev 2005, 14:1052-1059.

24. Kato I, Beinart C, Bleich A, Su S, Kim M, Toniolo PG: A nested case-control study of mammographic patterns, breast volume, and breast cancer (New York City, NY, United States). Cancer Causes Control 1995, 6:431-438.

25. Vachon CM, Sellers TA, Pankratz VS: Mammographic density of the breast: to the editor. N Engl J Med 2003, 348:174.

26. Boyd NF, Hopper JL: Mammographic density of the breast: the authors reply. N Engl J Med 2003, 348:174-175.

27. Hankinson S, Hunter DJ: Breast cancer. In Textbook of Cancer Epidemiology Edited by: Adami HO HD, Trichopoulos D. New York: Oxford University Press; 2002:301-339.

28. Boyd NF, Stone J, Martin LJ, Jong R, Fishell E, Yaffe M, Hammond $\mathrm{G}$, Minkin S: The association of breast mitogens with mammographic densities. Br J Cancer 2002, 87:876-882.

29. Byrne C, Colditz GA, Willett WC, Speizer FE, Pollak M, Hankinson SE: Plasma insulin-like growth factor (IGF) I, IGF-binding protein 3, and mammographic density. Cancer Res 2000, 60:3744-3748.

30. Bremnes Y, Ursin G, Bjurstam N, Lund E, Gram IT: Different types of postmenopausal hormone therapy and mammographic density in Norwegian women. Int J Cancer 2006.

31. McTiernan A, Martin CF, Peck JD, Aragaki AK, Chlebowski RT, Pisano ED, Wang CY, Brunner RL, Johnson KC, Manson JE, et al:: Estrogen-plus-progestin use and mammographic density in postmenopausal women: women's health initiative randomized trial. J Natl Cancer Inst 2005, 97:1366-1376.

32. Cuzick J, Warwick J, Pinney E, Warren RM, Duffy SW: Tamoxifen and breast density in women at increased risk of breast cancer. J Natl Cancer Inst 2004, 96:621-628.

33. Smid M, Wang Y, Klijn JG, Sieuwerts AM, Zhang Y, Atkins D, Martens JW, Foekens JA: Genes associated with breast cancer metastatic to bone. J Clin Oncol 2006, 24:2261-2267.

34. Stacey SN, Manolescu A, Sulem P, Rafnar T, Gudmundsson J, Gudjonsson SA, Masson G, Jakobsdottir M, Thorlacius S, Helgason A, Aben KK, Strobbe LJ, Albers-Akkers MT, Swinkels DW, Henderson BE, Kolonel LN, Le Marchand L, Millastre E, Andres R, Godino J, Garcia-Prats MD, Polo E, Tres A, Mouy M, Saemundsdottir J, Backman VM, Gudmundsson L, Kristjansson K, Bergthorsson JT, Kostic J, et al:: Common variants on chromosomes $2 q 35$ and $16 q 12$ confer susceptibility to estrogen receptorpositive breast cancer. Nat Genet 2007, 39:865-869.

35. Smith P, McGuffog L, Easton DF, Mann GJ, Pupo GM, Newman B, Chenevix-Trench G, kConFab Investigators, Szabo C, Southey M, Renard H, Odefrey F, Lynch H, Stoppa-Lyonnet D, Couch F, Hopper JL, Giles GG, McCredie MR, Buys S, Andrulis I, Senie R, BCFS, BRCAX Collaborators Group, Goldgar DE, Oldenburg R, Kroeze-Jansema K, Kraan J, Meijers-Heijboer H, Klijn JG, van Asperen $\mathrm{C}$, van Leeuwen I, et al.: A genome wide linkage search for breast cancer susceptibility genes. Genes Chromosomes Cancer 2006, 45:646-655.

36. Hunter DJ, Kraft P, Jacobs KB, Cox DG, Yeager M, Hankinson SE, Wacholder S, Wang Z, Welch R, Hutchinson A, Wang J, Chatterjee N, Orr N, Willett WC, Colditz GA, Ziegler RG, Berg CD, Buys SS, McCarty CA, Feigelson HS, Calle EE, Thun MJ, Hayes RB, Tucker M, Gerhard DS, Fraumeni JF Jr., Hoover RN, Thomas G, Chanock SJ: A genome-wide association study identifies alleles in FGFR2 associated with risk of sporadic postmenopausal breast cancer. Nat Genet 2007, 39:870-874.

37. Lee E, Haiman CA, Ma H, Berg D Van Den, Bernstein L, Ursin G: The role of established breast cancer susceptibility Loci in mammographic density in young women. Cancer Epidemiol Biomarkers Prev 2008, 17:258-260. 